\title{
GAMBARAN URINALISA PASIEN HIPERTENSI RAWAT INAP DAN RAWAT JALAN DI RUMAH SAKIT LABUANG BAJI
}

\author{
Tadjuddin Naid, Fitriani Mangarengi, Nursina
}

Fakultas Farmasi Universitas Hasanuddin Makassar

Email : tadjuddinnaid@yahoo.co.id

\begin{abstract}
A research has been done about urinalysis profile on patient hypertension inpatient and outpatient at Labuang Baji Hospital was performed. The aim of this research was to determine urinalysis profile on hypertension patient. This research is an descriptive study with cross sectional method with total amount of sample was 30 samples. The research result showed that hypertension patient who have hypertension grade 1 found on 23 (76.7\%) people and there were 7 (23.3\%) people who have hypertension grade II with urinalysis profile as the following, the most numerous age groups were $46-50$ years old (50.0\%), where females (66.7\%) most numerous than males (33.3\%) and the most numerous hypertension grade I found on inpatient (84.2\%) than the outpatient (63.6\%) and most numerous hypertension grade II found on inpatient (36.4\%) than outpatient (15.8\%). Urinalysis profile in hypertension grade I almost same with hypertension grade II but there was difference profile in hypertension grade II such as protein, ascorbic acid increase compared hypertension grade $I$.
\end{abstract}

Key words: Urinalysis, hypertension, glucose, protein, ascorbic acid

\section{PENDAHULUAN}

Hipertensi adalah peningkatan tekanan darah dimana tekanan sistolik $\geq 140 \mathrm{mmHg}$ dan tekanan diastolik $\geq$ $90 \mathrm{mmHg}$. Hipertensi sering kali disebut silent killer karena termasuk penyakit yang mematikan, sering tanpa gejala, kalaupun ada gejala tersebut seringkali di anggap sebagai gangguan biasa $(1,2)$.

Perkembangan hipertensi dari tahun ke tahun mengalami peningkatan.Tahun 2000 pasien hipertensi di dunia mencapai jumlah
957-987 juta orang. Tahun 2025 jumlahnya akan meningkat menjadi 1,5 milyar orang atau $60 \%$ dari populasi jumlah penduduk dewasa dunia, apabila usaha-usaha pencegahan terhadap hipertensi tidak dilakukan sedini mungkin (1).

Hipertensi menjadi masalah kesehatan yang serius, karena jika tidak terkendali akan berkembang dan menimbulkan komplikasi, seperti stroke, penyakit jantung, gagal ginjal. Komplikasi tersebut sering dirujuk sebagai kerusakan akhir organ tubuh, 
Gambaran Urinalisa Pasien Hipertensi Rawat Inap Dan Rawat Jalan Di Rumah Sakit Labuang Baji

untuk itu monitoring tekanan darah tinggi sangat penting dilakukan secara rutin dan berkelanjutan (2).

Tekanan darah dipengaruhi oleh cardiac output (curah jantung) yaitu volume darah yang dipompakan oleh tiap-tiap ventrikel kiri menuju aorta per menit. Ketika seseorang mengalami stres, cortex otak akan memerintahkan hypothalamus untuk mempengaruhi vasomotor pada medulla oblongata untuk mengatur diameter arteriol. Hal ini akan memicu sistem syaraf simpatis sehingga terjadi vasokontriksi dengan menaikkan curah jantung sehingga tekanan darah meningkat (1).

Protein didalam urin (proteinuria) merefleksikan kerusakan ginjal. Gagal ginjal dapat terjadi karena kerusakan progresif akibat tekanan tinggi pada kapiler-kapiler ginjal, glomerulus. Dengan rusaknya glomerulus, darah akan mengalir keunit-unit fungsional ginjal, nefron akan terganggu dan dapat berlanjut menjadi hipoksia dan kematian. Dengan rusaknya membran glomerulus, protein akan keluar melalui urin sehingga tekanan osmotik koloid plasma berkurang, menyebabkan edema yang sering dijumpai pada hipertensi kronik ( 3 ).
Tes laboratorium bertujuan membantu menentukan penyakit atau diagnosis, membantu prognosis, memantau perjalanan penyakit atau memonitor pengobatan dengan cara pemeriksaan spesimen atau sampel dari pasien. Salah satu tes yang dilakukan adalah urinalisis atau analisa urin ( 4 ).

Urinalisis adalah tes yang dilakukan pada sampel urin pasien untuk tujuan diagnosis dan evaluasi berbagai jenis penyakit ginjal, memantau perkembangan penyakit seperti diabetes dan tekanan darah tinggi (hipertensi) dan skrining terhadap status kesehatan umum. $(4,5)$

Urin berasal dari darah atau plasma yang mengalami filtrasi oleh glomerulus kemudian disekresi, diabsorbsi dan dieksresi melalui saluran kemih. Berdasarkan uraian di atas maka akan dilakukan penelitian dengan rumusan masalah adalah bagaimanakah gambaran urin pasien hipertensi . Tujuan penelitian adalah untuk mengetahui gambaran urin pada pasien hipertensi yang rawat inap dan rawat jalan. Manfaat dari penelitian ini diharapkan dapat menambah informasi ilmiah mengenai gambaran urin pada pasien hipertensi. Dapat membantu dalam memfollow up penyakit hipertensi. 
Gambaran Urinalisa Pasien Hipertensi Rawat Inap Dan Rawat Jalan Di Rumah Sakit Labuang Baji

\section{METODOLOGI PENELITIAN}

\section{A. Desain Penelitian}

Penelitian ini merupakan studi analitik deskriftif dengan pendekatan croos sectional terhadap spesimen urin penderita hipertensi.

B. Tempat Penelitian :

Penelitian dilakukan di

Rumah Sakit Labuang Baji Makassar.

C. Populasi dan Perkiraan Besar Sampel

Populasi sampel adalah penderita penyakit hipertensi yang rawat inap dan rawat jalan di Rumah Sakit Labuang Baji Makassar. Sampel adalah semua populasi terjangkau yang memenuhi kriteria penelitian di Rumah Sakit Labuang Baji Makssar. Besar sampel diperkirakan dengan Rumus (8):

$\mathrm{n}=\frac{Z \mathrm{a}^{2} \mathrm{PQ}}{\mathrm{d}^{2}}$

\section{Keterangan :}

\section{$\mathrm{n}=$ Besar sampel}

$\mathrm{z}_{\alpha}=$ Deviat baku normal untuk tingkat kemaknaan, $\alpha$ (ditetapkan). Nilai $\alpha$ ini dipilih sesuai dengan IK yang diinginkan, bila IK 95\% berarti $\alpha=0,05$, sehingga $z_{\alpha}=$ 1,96 .

$$
\begin{aligned}
P= & \text { Proporsi atau keadaan yang } \\
& \text { akan dicari (dari pustaka) } \\
& \text { atau perkiraan proporsi } \\
& \text { penyakit/efek pada populasi } \\
& \text { dari peneliti sebelumnya. } P \text { : } \\
& 0,09 \\
Q= & 1-P(0,91) \\
d= & \text { Tingkat ketepatan absolut } \\
& \text { yang dikehendaki }=0,1
\end{aligned}
$$

Jumlah sampel minimal dalam penelitian ini:

$$
\begin{aligned}
& \mathrm{n}=\frac{Z \mathrm{a}^{2} \mathrm{PQ}}{\mathrm{d}^{2}} \\
& \mathrm{n}=\frac{(1,96)^{2} \cdot(0,09) \cdot(0,91)}{(0,1)^{2}}
\end{aligned}
$$

$\mathrm{n}=31,4 ;$ dibulatkan menjadi 30 sampel

\section{Kriteria Sampel}

\section{a. Kriteria Inklusi}

1. Subjek penelitian ini adalah pasien yang memeriksakan urinnya di Laboratorium RSU Labuang Baji Makassar dan didiagnosa oleh dokter sebagai penderita Hipertensi

2. Mengajukan permintaan tes urin.

3. Penderita hipertensi Usia dewasa baik laki-laki maupun wanita.

\section{b. Kriteria Eksklusi}

1. Penderita wanita yang sedang mengalami menstruasi. 
Gambaran Urinalisa Pasien Hipertensi Rawat Inap Dan Rawat Jalan Di Rumah Sakit Labuang Baji

\section{Penderita wanita yang sedang hamil.}

\section{E. Alat dan Bahan Penelitian}

Alat-alat yag digunakan dalam penelitian ini adalah Urine analizer, Tabung reaksi, Kertas tissue, Rak tabung, pipet tetes, lampu spiritus. Adapun bahanbahan yang digunakan adalah reagen strip test : Uriscan strip reagen, dan sampel yang digunakan : urin sewaktu.

\section{F. Prosedur Penelitian}

\section{Alokasi subjek.}

Penelitian dilakukan pada semua sampel yang telah didiagnosis memiliki tekanan darah di atas nilai normal ( $>140 / 90 \mathrm{mmHg}$ ) yang memiliki kriteria sampel yang melakukan pemeriksaan dirumah sakit Labuang Baji.

\section{Cara penelitian}

a. Melakukan pencatatan identitas pasien yang memenuhi kriteria sampel dan memberikan penjelasan lengkap mengenai hal apa saja yang akan dilakukan terhadap mereka.

b. Pasien menjalani pemeriksaan tekanan darah dengan spgymomanometer. c. Pasien menjalani pemeriksaan laboratorium dengan sampel urin

d. Pengumpulan spesimen urin 1) Tangan di cuci menggunakan sabun kemudian dikeringkan dengan handuk atau tissu

2) Urin dikeluarkan, aliran yang pertama dibuang, aliran selanjutnya ditampung dalam wadah yang sudah disiapkankan

3) Urin selesai ditampung sebelum aliran urin habis.

\section{G. Pemeriksaan Urin}

\section{Metode carik celup}

a. Prinsip :

Sampel di dalam
tabung akan bereaksi,
setelah pada permukaan
strip urine yang telah dilapisi
kertas sellusosa berupa
adanya perubahan warna
pada masing-masing
parameter, selanjutnya akan
dianalisa pada alat Uriscan
Pro S-300

b. Cara kerja :

Tes dilakukan dengan alat automatik Uriscan Pro 
Gambaran Urinalisa Pasien Hipertensi Rawat Inap Dan Rawat Jalan Di Rumah Sakit Labuang Baji

S-300. Data pasien berupa nama dan no pemeriksaan dituliskan di wadah yang telah disiapkan. Kemudian On-kan alat urin analyzer. Selanjutnya Uriscan strip reagen dicelupkan ke dalam urin selama \pm 1 menit, Rembesan urin dibersihkan dengan kertas tissu. Strip diletakkan pada chamber alat urin analyzer. Proses identifikasi berlangsung dan hasil akan keluar melalui print out.

\section{HASIL PENELITIAN}

Penelitian telah dilaksanakan di Laboratorium RSUD Labuang Baji Makassar pada tanggal 12 Maret sampai dengan tanggal 9 April 2012. Subjek penelitian yaitu adalah pasien Hipertensi rawat inap dan rawat jalan di RSUD Labuang Baji Makassar dengan permintaan tes urin dengan jumlah sampel sebanyak 30 orang dengan rentang usia pasien $46-66$ tahun. Terdapat jumlah pasien rawat inap 11 orang dan pasien rawat jalan 19 orang.

Tabel 1. Data dasar penelitian pasien Hipertensi di RSUD Labuang Baji Makassar

\begin{tabular}{lll}
\hline \multicolumn{1}{c}{ Parameter } & Frekuensi & $\%$ \\
\hline $\begin{array}{l}\text { Jenis Kelamin } \\
\text { Laki-laki }\end{array}$ & 10 & 33,3 \\
Perempuan & 20 & 66,7 \\
\hline Umur & & \\
46-50 tahun & 15 & 50,0 \\
51-55 tahun & 8 & 26,7 \\
56-60 tahun & 5 & 16,7 \\
$\quad>60$ tahun & 2 & 6,7 \\
\hline Tekanan Darah & \multicolumn{2}{c}{} \\
Hipertensi tingkat I $(140-159 / 90-99)$ & 23 & 76,7 \\
Hipertensi tingkat II $(\geq 160 / \geq 100)$ & 7 & 23,3 \\
\hline Perawatan & \multicolumn{2}{c}{} \\
Rawat Inap & 11 & 36,7 \\
Rawat Jalan & 19 & 63,3 \\
\hline
\end{tabular}

Dari tabel diatas menunjukkan bahwa dari 30 sampel penelitian didapatkan jumlah laki-laki sebanyak 10 orang $(33,3 \%)$ dan perempuan 20 orang $(66,7 \%)$. Untuk umur terbanyak ditemukan pada umur 46- 50 tahun yaitu 15 orang $(50,0 \%)$, kemudian umur 51-55 tahun sebanyak 8 orang $(26,7 \%)$, untuk umur antara 56-60 tahun sebanyak 5 orang $(16,7 \%)$ dan untuk umur $>60$ tahun sebanyak 2 orang $(6,7 \%)$. Untuk pemeriksaan tekanan darah di dapatkan yang mengalami hipertensi tingkat I 
Gambaran Urinalisa Pasien Hipertensi Rawat Inap Dan Rawat Jalan Di Rumah Sakit Labuang Baji

sebanyak 23 orang $(76,7 \%)$ dan orang $(36,7 \%)$ dan rawat jalan 19 hipertensi tingkat II 7 orang ( $23,3 \%)$ orang $(63,3 \%)$.

Untuk sampel rawat inap sebanyak 11

Tabel 2. Karakteristik penelitian Hipertensi di RSUD Labuang Baji

\begin{tabular}{ccc}
\hline & \multicolumn{2}{c}{ Hipertensi } \\
\cline { 2 - 3 } & Hipertensi tingkat I N ( \% ) & Hipertensi tingkat II N ( \%) \\
\hline Perawatan & $7(63,6)$ & $4(36,4)$ \\
Rawat Inap & $16(84,2)$ & $3(15,8)$ \\
Rawat jalan & $13(86,7)$ & $2(13,3)$ \\
\hline Umur & $7(87,5)$ & $1(12,5)$ \\
$46-50$ tahun & $2(40,0)$ & $3(60,0)$ \\
$51-55$ tahun & $1(50,0)$ & $1(50,0)$ \\
$56-60$ tahun & $8(34,8 \%)$ & $2(28,6 \%)$ \\
$>60$ tahun & $15(65,2 \%)$ & $5(71,4 \%)$ \\
\hline Jenis Kelamin & & \\
Laki-laki &
\end{tabular}

Tabel 3. Hasil Tes urinalisa pasien hipertensi di RSUD Labuang Baji Makassar

\begin{tabular}{ccc}
\hline Parameter & \multicolumn{2}{c}{ Nilai } \\
\cline { 2 - 3 } & Hipertensi tingkat I & Hipertensi tingkat II \\
\hline Eritrosit & Negative & Negatif \\
Bilirubin & Negatif & Negative \\
Urobilinogen & Normal & Normal \\
Keton & Negative & Negative \\
Protein & $\pm 10-+30 \mathrm{mg} / \mathrm{dl}$ & $+2(100 \mathrm{mg} / \mathrm{dl})$ \\
Nitrit & Negative & Negative \\
Glukosa & Negative & $6,5-7,5$ \\
Ph & $5,5-6,5$ & $1,010-1,025$ \\
Berat jenis & $1,010-1,025$ & Positif $+10 \mathrm{wbc} / \mathrm{ul}$ \\
Leukosit & Negative & Negative \\
Vitamin c & $+10 \mathrm{mg} / \mathrm{dl}$ &
\end{tabular}

\section{PEMBAHASAN}

Hipertensi erat kaitannya dengan ginjal dimana ketika seseorang menderita hipertensi maka kemungkinan besar akan mengalami kerusakan ginjal. Karena filter dari ginjal atau glomerulus mendapatkan tekanan darah yang sangat tinggi, jika terjadi secara terus-menerus maka akan terjadi kebocoran pada ginjal. Berdasarkan data hasil penelitian 30 sampel pasien di RSUD Labuang Baji Makassar, 10 orang laki-laki (33,3\%) dan 20 orang perempuan (66,7\%). Terdapat jumlah pasien perempuan yang lebih banyak dalam penelitian ini, karena distribusi sampel penelitian di dapatkan pasien yang menderita 
Gambaran Urinalisa Pasien Hipertensi Rawat Inap Dan Rawat Jalan Di Rumah Sakit Labuang Baji

hipertensi di RSUD Labuang Baji adalah perempuan. Dari data the Joint National Comitte (JNC), ditemukan prevalensi hipertensi pada laki-laki $59,1 \%$ dan perempuan $61,0 \%$. Sugiri dijawa tengah mendapatkan angka prevalansi $6,0 \%$ untuk pria dan $11,6 \%$ untuk perempuan. Prevalensi di Sumatra barat dimana pria $18,6 \%$ dan perempuan $17,4 \%$, sedangkan daerah perkotaan dijakarta (pertukangan) didapatkan $14,6 \%$ pria dan $13,7 \%$ perempuan. Menurut penelitian yang dilakukan oleh Ade Dian Anggraini jumlah penderita hipertensi yang berjenis kelamin laki-laki $(45,7 \%)$ dan wanita $(54,3 \%)$. Namun berdasarkan laporan dari National Health and Nutrition Examination Survery (NHNES), prevalensi hipertensi antara penderita dengan jenis kelamin lakilaki dan jenis kelamin perempuan masih menjadi kontroversi. $(6,7)$

Dari tabel 1 menunjukkan lebih banyak pada kelompok umur 46 - 50 tahun. Kondisi yang berkaitan dengan usia ini adalah produk samping dari keausan ateriosklerosis dari arteriarteri utama, terutama aorta dan akibat dari berkurangnya kelenturan. Dengan bertambahnya umur, risiko terkena hipertensi lebih besar sehingga prevalensi dikalangan usia lanjut cukup tinggi yaitu sekitar $40 \%$ dengan kematian sekitar $50 \%$ diatas umur 60 tahun. Hipertensi lebih banyak terjadi pada pria bila terjadi pada usia dewasa muda. Tetapi lebih banyak menyerang wanita setelah umur 50 tahun, sekitar $60 \%$ penderita hipertensi adalah wanita. Hal ini sering dikaitkan dengan perubahan hormon ekstrogen setelah menopause.

Pada gambar 1 menunjukkan bahwa jumlah populasi sampel lebih banyak hipertensi tingkat I pada pasien rawat jalan daripada hipertensi tingkat II. Sementara untuk populasi hipertensi tingkat II lebih banyak pada rawat inap dari rawat jalan. Pasien hipertensi tingkat I rutin melakukan rawat jalan dan checkup laboratorium untuk pengendalian hipertensi. Sementara hipertensi tingkat II sudah mengalami komplikasi sehingga perlu penanganan khusus.

Dari tabel 3 menunjukkan bahwa dari hasil pemeriksaan hasil untuk hipertensi tingkat I dan tingkat II di dapatkan hasil yang hampir sama. Tetapi yang membedakan pada parameter protein dan vitamin C. meningkat pada hipertensi tingkat I, sedang glukose dan leukosit meningkat pada hipertensi tingkat II. Tekanan darah yang tinggi dan tidak terkontrol pada penderita hipertensi dapat merusak jaringan pembuluh 
Gambaran Urinalisa Pasien Hipertensi Rawat Inap Dan Rawat Jalan Di Rumah Sakit Labuang Baji

darah ginjal sehingga terjadi peradangan pada glomerulus yang bertugas untuk menyaring darah sehingga ginjal tidak dapat berfungsi sebagaimana mestinya akibat adanya kerusakan pada ginjal, darah yang diterima unit penyaring menjadi lebih sedikit dan tekana darah di dalam ginjal tidak bisa dikendalikan sehingga zat buangan bisa masuk kembali ke dalam darah dan zat kimia yang dibutuhkan tubuh dan protein akan keluar ikut bersama urin.

Nilai glukosa yang meningkat pada pasien hipertensi tingkat II merupakan hipertensi sekunder yaitu hipertensi yang di sebabkan oleh penyakit lain misalnya diabetes mellitus bukan hipertensi primer (esensial) yaitu hipertensi yang tidak diketahui penyebabnya. Pada orang normal tidak didapati glukosa dalam urin. Glukosaria dapat terjadi karena peningkatan kadar glukosa dalam darah yang melebihi kapasitas maksimun tubulus untuk mereabsorpsi glukosa seperti pada diabetes mellitus.

\section{KESIMPULAN}

Berdasarkan hasil penelitian yang telah dilakukan, dapat disimpulkan bahwa penderita hipertensi rawat inap dan rawat jalan terbanyak mengalami hipertensi tingkat I dengan gambaran urinalisa sebagai berikut :

Gambaran urinalisa antara hipertensi tingkat | dan tingkat || hampir sama hasil yang di dapatkan tapi yang membedakan adalah pada hipertensi tingkat I parameter protein dan vitamin $\mathrm{C}$ meningkat dibandingkan hipertensi tingkat II,sedang glukose dan leukosit meningkat pada hipertensi tingkat II dibandingkan hipertensi tingkat I.

\section{DAFTAR PUSTAKA}

Ridwan, Muhammad. Mengenal, Mencegah, Mengatasi Silent Killer Hipertensi. Pustaka Widyamara. Semarang. 2009

http://www.ptaskes.com/uploads/artikel /HIPERTENSI.pdf [ diakses tanggal 10 maret 2010 ]

Brunner \& Suddart. Buku Ajar Keperawatan Medical-bedah. Edisi 8 Volume II. Terjemahan EGC. Jakarta. 2002.

Soewoto Hafiz, H. Biokimia eksperimen laboratorium. Universitas Indonesia Fak.Kedokteran Bag.Biokimia. Jakarta. 2001

Hardjoeno \& Fitriani . Substansi dan cairan tubuh, penerbit LEPHAS, Makasaar. 2007

Dian Ade Anggraini. 2008. Faktorfaktor yang behubungan dengan kejadian hipertensi pada pasien yang berobat dipoliklinik dewasa puskesmas Bangkunan [serial on the internet]. 26 juni 2008. 
Gambaran Urinalisa Pasien Hipertensi Rawat Inap Dan Rawat Jalan Di Rumah Sakit Labuang Baji

Available from.

Urin Metode Carik Celup.

http://www.yayanakhyar.wordp

ress.com

Departemen Kesehatan

Republik Indonesia. Jakarta . 2004.

Yundini.2006.Factor resiko terjadinya hipertensi [serial on the internet] 29 agustus 2006. Available from http://docs.yahoo.com//np/Ter $\underline{\mathrm{ms} /}$

Dahlan, S.M. Besar sampel dan cara pengambilan sampel dalam penelitian kedokteran dan kesehatan. Salemba Medika. Jakarta. 2009.

Direktorat Jendral pelayanan medik. Pedoman Pemeriksaan Kimia

Kaplan LA, Pesce AJ, Kazmiesczak Sc. Clinical Chemistry Theory, Analysis, Correlation. 4th Ed.Mosby An Affiliate of Elseuier St louis, Missouri 2003.

Sudiono $H$, Iskardar I, Halim SL, Santoso $R, \quad$ sinsanta. Urinalisis. Fakultas Kedokteran Universitas Kristen Krida Wacana (UKRIDA). Jakarta. 2006 